\title{
Occurrence and risk factors of zoonoses in dogs and owners in Sertão, Paraíba State, Northeastern Brazil
}

\section{Ocorrência e fatores de risco para zoonoses em cães e proprietários no Sertão do Estado da Paraíba, Nordeste do Brasil}

\author{
Annielle Regina da Fonseca Fernandes ${ }^{1}$; Diego Figueiredo da Costa ${ }^{1}$; \\ Carla Lauise Rodrigues Menezes Pimenta ${ }^{1}$; Kamila Nunes de Araújo ${ }^{2}$; \\ Raizza Barros Sousa Silva ${ }^{1}$; Marcia Almeida de Melo ${ }^{3}$; Hélio Langoni ${ }^{4}$; \\ Rinaldo Aparecido Mota ${ }^{5}$; Sérgio Santos de Azevedo ${ }^{3 *}$
}

\begin{abstract}
Seropositivity and risk factors for visceral leishmaniasis, Chagas disease, toxoplasmosis, and leptospirosis were investigated in 200 dogs and twenty-three owners in a municipality with a history of human cases of visceral leishmaniasis and toxoplasmosis in the region of Sertão, Paraíba State, Northeastern Brazil. In dogs, frequencies of $6 \%$ (95\% confidence interval $[\mathrm{CI}]=2.7-9.3 \%), 7.5 \%(95 \%$ $\mathrm{CI}=3.8-11.2 \%), 18 \%(95 \% \mathrm{CI}=12.7-23.3 \%)$, and $14 \%(95 \% \mathrm{CI}=9.2-18.8 \%)$ were found for visceral leishmaniasis, Chagas disease, toxoplasmosis, and leptospirosis, respectively. An age of over 72 months and environment conditions (soil) were identified as risk factors for Leishmania chagasi infection. Free housing was identified as risk factor for Trypanosoma cruzi infection. For toxoplasmosis, free housing and contact with cats were found to be risk factors, while commercial food was a risk factor for leptospirosis. Of the twenty-three owners who agreed to participate in the study, eight were tested for leishmaniasis, three for Chagas disease, nine for toxoplasmosis, eleven for leptospirosis, and five were tested for more than one disease. Only anti-Toxoplasma gondii antibodies were found in the human population at a frequency of $44.4 \%$ (4/9); for all other diseases, all individuals were negative. The results indicate that such zoonoses are present in dogs from the studied region, but only toxoplasmosis was found in the owners. Our risk analysis suggests that cleaner soil, better storage of dog food, and avoiding free housing can reduce the risk of infection by these diseases.
\end{abstract}

Key words: Canine. Guardians. Transmissible diseases. Epidemiology.

1 Discentes, Programa de Pós-Graduação em Medicina Veterinária, Unidade Acadêmica de Medicina Veterinária, Universidade Federal de Campina Grande, UFCG, Campus de Patos, Patos, PB, Brasil. E-mail: anni.regina@gmail.com; diegoveter@hotmail. com; carlalauise@hotmail.com

2 Médica Veterinária, Laboratório de Análises Clínicas Animal Vet Lab, Patos, PB, Brasil. E-mail: kamila vet@hotmail.com

3 Profs., Programa de Pós-Graduação em Medicina Veterinária, Unidade Acadêmica de Medicina Veterinária, UFCG, Campus de Patos, Patos, PB, Brasil. E-mail: longipalpis@gmail.com; sergio@vps.fmvz.usp.br

4 Prof., Departamento de Higiene Veterinária e Saúde Pública, Faculdade de Medicina Veterinária e Zootecnia, FMVZ, Universidade Estadual Paulista, UNESP, Campus de Botucatu, Botucatu, SP, Brasil. E-mail: hlangoni@fmvz.unesp.br

5 Prof., Laboratório de Doenças Infectocontagiosas dos Animais Domésticos, Departamento de Medicina Veterinária, Universidade Federal Rural de Pernambuco, UFRPE, Recife, PE, Brasil. E-mail: rinaldo.mota@hotmail.com

* Author for correspondence

Received: May 19, 2017 - Approved: Mar. 02, 2018 


\section{Resumo}

Foram investigados a soropositividade e os fatores de risco para leishmaniose visceral, doença de Chagas, toxoplasmose e leptospirose em 200 cães e 23 proprietários em um município do Sertão paraibano com histórico de casos humanos de leishmaniose visceral e toxoplasmose. Nos cães, foram encontradas frequências de $6 \%$ (IC 95\% = 2,7\% - 9,3\%), 7,5\% (IC 95\% = 3,8\% - 11,2\%), 18\% (IC 95\% = 12,7\% $23,3 \%$ ) e $14 \%$ (IC $95 \%=9,2 \%$ - 18,8\%) para leishmaniose visceral, doença de Chagas, toxoplasmose e leptospirose, respectivamente. A idade $>72$ meses e habitar em ambiente de terra foram apontados como fatores de risco para infecção por Leishmania chagasi. A criação solta, ou seja, não domiciliado, foi considerada como fator de risco para infecção por Trypanosoma cruzi. Para toxoplasmose, as categorias criação solta e contato com gatos foram fatores de risco, enquanto que para leptospirose a dieta à base de ração comercial. Dos vinte e três proprietários que aceitaram participar da pesquisa, oito foram testados para leishmaniose, três para doença de Chagas, nove para toxoplasmose, 11 para leptospirose e cinco indivíduos foram testados para mais de uma doença. Apenas anticorpos anti-Toxoplasma gondii foram encontrados na população humana com frequência de 44,4\% (4/9), e para as demais doenças todos os indivíduos foram negativos. Os resultados indicam que tais zoonoses estão presentes nos cães da região estudada, e nos proprietários apenas toxoplasmose foi verificada. Na análise de riscos sugere-se maiores cuidados com ambientes de terra onde são criados os cães e com o armazenamento da ração, e evitar animais soltos na rua.

Palavras-chave: Caninos. Tutores. Doenças transmissíveis. Epidemiologia.

\section{Introduction}

The presence of dogs in our society is increasing; they occupy special positions in home environments. The increased importance given to dogs by our society requires increased attention to be given to their health status, especially regarding the diseases that are naturally transmitted from animals to humans, the zoonosis. In many cases, although the animals appear healthy, they may suffer from conditions such as canine visceral leishmaniasis (CVL), Chagas disease (CD), toxoplasmosis, and leptospirosis; they may become major sources of infection from close contact with humans for long periods. Therefore, it is important to study these diseases in dogs to evaluate the overall risk of zoonotic infection in certain communities.

In Brazil, CVL and CD are major zoonotic diseases that can cause severe symptoms in humans. These diseases are caused by Leishmania chagasi and Trypanosoma cruzi protozoa, respectively; both are transmitted by hematophagous insects acting as vectors (Lutzomyia spp. and Triatoma spp.); stray and domestic dogs are major reservoirs of these parasites (LUCIANO et al., 2009).
Toxoplasmosis, a widespread zoonotic disease worldwide caused by Toxoplasma gondii, uses domestic and stray cats as definitive hosts, and is therefore able to infect humans and other homeothermic animals (ULLMANN et al., 2008). Dogs are potentially at risk to transmit the pathogen, since this species is not considered a protozoandefinitive host, but rather acts as a mechanical vehicle for oocysts. This allows them to become sentinels for infection (DUBEY et al., 2007).

Leptospirosis, an infectious disease caused by pathogenic bacteria of the genus Leptospira, is among the most common zoonotic diseases worldwide. This is because of the wide spectrum of infection and the dissemination of the bacteria across all continents (ALVES et al., 2003; BATISTA et al., 2004). Since the most prevalent serovars in humans are L. icterohaemorrhagiae and L. canicola, it was verified that, excluding synanthropic rodents, dogs are the most common source of infection, as the bacteria are capable of excreting live Leptospira in the urine for long and intermittent periods without presenting clinical signs of the disease (LILENBAUM et al., 2005). 
The use of sentinel animals as public health indicators allows for the acquisition of important information. Additionally, it allows researchers to identify endemic regions, environmental risk factors, emerging and re-emerging diseases, and new outbreaks of some pathogens (DE NARDO, 1997). Thus, zoonosis monitoring and control, carried out through the development of serum-epidemiological surveys for every geographic location, is required; it is vital to fund the governmental organizations responsible for the structuring and direction of new public policies aimed at strengthening public health in general.

The goal of this study was to determine the epidemiological status of CVL, CD, leptospirosis, and toxoplasmosis in dogs from Sertão in Paraíba State, the subsequent seropositivity of humans exposed to seropositive dogs, and to identify risk factors for those infections in the canine population.

\section{Materials and Methods}

This study was approved by the Ethics Research Committee of the University Hospital Alcides Carneiro, Federal University of Campina Grande (CEP/HU/UFCG), under the reference number 1707230, and by the Animals Ethics Committee (CEUA/CESED) of the Faculty of Medical Sciences of Campina Grande-PB (FCM), under the reference number 0041/280314.

The study was carried out in the municipality of Brejo do Cruz in Paraíba State, $420 \mathrm{~km}$ from the state capital of João Pessoa. This area includes the geographic regions of Brazilian semi-arid biomes and mesoregions of Sertão in Paraíba. Its estimated population in 2016 was 14,006 inhabitants, distributed over a $399 \mathrm{~km}^{2}$ area with a MHDI (Municipal Human Development Index) of 0.597 (IBGE, 2017). The choice of the municipality in which to conduct the study was determined by reported human cases of visceral leishmaniasis and toxoplasmosis in recent years, which was confirmed and recorded in the Brazilian Information System for Notifiable Diseases (SINAN). Reported cases included children and pregnant women. In the last five years, one case of gestational toxoplasmosis and three cases of visceral leishmaniasis were reported and treated, with no deaths recorded.

A total of 200 dogs aged 3 months or older, were used in the study. Candidates were selected by visiting the homes of dog owners with at least one animal and one human contactant per visited home. The region included different neighborhoods from different locations in equidistant areas. From December 2014 to October 2015, blood samples were collected by external jugular, cephalic, or lateral saphenous vein puncture without the use of anticoagulant compounds. The samples were centrifuged and stored at $-20{ }^{\circ} \mathrm{C}$. Dog owners were also asked to complete an epidemiological survey in order to provide data aimed at verifying the presence or absence of certain practices and conditions that could act as risk factors for zoonosis (Table 1). The collection of blood from human contactants was conducted by a biomedical or pharmaceutical biochemical professional after the individuals signed informed consent. The serum was separated and stored at $-20{ }^{\circ} \mathrm{C}$ until serological tests were conducted.

For dogs, CVL, CD, and toxoplasmosis tests were performed with the aid of IndirectImmunofluorescent Antibody Test (IFAT) (CAMARGO; REBONATO, 1966; CAMARGO, 1964, 1966). The samples were initially examined at a cutoff dilution of 1:40 (CVL), 1:40 (CD), and 1:16 (toxoplasmosis). Those with a positive result were titrated until a final titer was obtained. For leishmaniasis, the samples underwent an enzyme-linked immunosorbent assay (ELISA) S7 test, according to the manufacturer's instructions (Biogene Indústria \& Comercio Ltda ME, Recife-PE, Brazil). For leptospirosis, the microscopic agglutination test (MAT) (OIE, 2014) was performed, and live antigens were then collected. These included eighteen Leptospira serovars: L. australis, autumnalis, bratislava, bataviae, canicola, castellonis, cynopteri, 
copenhageni, djasiman, grippotyphosa, guaricura, pomona, sejroe, tarassovi, and wolffi. In all analyses, hardjoprajitno, hebdomadis, icterohaemorrhagiae, positive and negative controls were also included.

Table 1. Univariate analysis of risk factors associated with seropositivity to Visceral leishmaniasis, Chagas disease, toxoplasmosis, and leptospirosis in 200 dogs from December 2014 to October 2015, in Sertão of Paraíba, Brazil.

\begin{tabular}{|c|c|c|c|c|c|c|c|c|c|}
\hline \multirow[b]{2}{*}{$\begin{array}{l}\text { Variable/ } \\
\text { Category }\end{array}$} & \multirow{2}{*}{$\begin{array}{c}\text { Total } \\
\text { number } \\
\text { of dogs }\end{array}$} & \multicolumn{2}{|c|}{ Leishmaniasis } & \multicolumn{2}{|c|}{ Chagas disease } & \multicolumn{2}{|c|}{ Toxoplasmosis } & \multicolumn{2}{|c|}{ Leptospirosis } \\
\hline & & $\begin{array}{l}\text { No. sero- } \\
\text { positive } \\
\text { cases }(\%)\end{array}$ & $P$ & $\begin{array}{l}\text { No. sero- } \\
\text { positive } \\
\text { cases }(\%)\end{array}$ & $P$ & $\begin{array}{l}\text { No. sero- } \\
\text { positive } \\
\text { cases }(\%)\end{array}$ & $P$ & $\begin{array}{l}\text { No. sero- } \\
\text { positive } \\
\text { cases }(\%)\end{array}$ & $P$ \\
\hline \multicolumn{10}{|l|}{$\begin{array}{l}\text { Level of school- } \\
\text { ing of the owner }\end{array}$} \\
\hline Illiterate & 15 & $0(0.0)$ & & $2(13.3)$ & & $4(26.7)$ & & $0(0.0)$ & \\
\hline 1st grade & 42 & $3(7.1)$ & & $2(4.8)$ & & $12(28.6)$ & & $0(0.0)$ & \\
\hline 2nd grade & 124 & $8(6.5)$ & & $11(8.9)$ & & $18(4.5)$ & & $24(19.4)$ & \\
\hline 3rd grade & 19 & $1(5.3)$ & 0.773 & $0(0.0)$ & 0.382 & $2(10.5)$ & $0.128^{*}$ & $4(21.1)$ & $0.005^{*}$ \\
\hline \multicolumn{10}{|l|}{ Sex } \\
\hline Male & 114 & $8(7.0)$ & & $9(7.9)$ & & $19(16.7)$ & & $14(12.3)$ & \\
\hline Female & 86 & $4(4.7)$ & 0.691 & $6(7.0)$ & 1.000 & $17(19.8)$ & 0.705 & $14(16.3)$ & 0.548 \\
\hline \multicolumn{10}{|l|}{ Age } \\
\hline 3-12 months & 69 & $3(4.3)$ & & $7(10.1)$ & & $8(11.6)$ & & $14(20.3)$ & \\
\hline $13-48$ months & 81 & $3(3.7)$ & & $3(3.7)$ & & $18(22.2)$ & & $10(12.3)$ & \\
\hline $49-72$ months & 30 & $2(6.7)$ & & $2(6.7)$ & & $3(10.0)$ & & $2(6.7)$ & \\
\hline$>72$ months & 20 & $4(20.0)$ & $0.045^{*}$ & $3(15.0)$ & 0.258 & $7(35.0)$ & $0.044^{*}$ & $2(10.0)$ & 0.255 \\
\hline \multicolumn{10}{|l|}{$\begin{array}{l}\text { Living } \\
\text { conditions }\end{array}$} \\
\hline Domestic & 123 & $9(7.3)$ & & $9(7.3)$ & & $13(10.6)$ & & $20(16.3)$ & \\
\hline Semi-domestic & 64 & $1(1.6)$ & & $2(3.1)$ & & $17(26.6)$ & & 7 (10.9) & \\
\hline Free housing & 13 & $2(15.4)$ & $0.098^{*}$ & $4(30.8)$ & $0.003 *$ & $6(46.2)$ & $0.001 *$ & $1(7.7)$ & 0.484 \\
\hline \multicolumn{10}{|l|}{ Diet } \\
\hline $\begin{array}{l}\text { Commercial } \\
\text { food }\end{array}$ & 76 & $6(7.9)$ & & $4(5.3)$ & & $7(9.2)$ & & $16(21.1)$ & \\
\hline Homemade food & 55 & $2(3.6)$ & & $5(9.1)$ & & $14(25.5)$ & & $3(5.5)$ & \\
\hline Rations + Food & 69 & $4(5.8)$ & 0.596 & $6(8.7)$ & 0.641 & $15(21.7)$ & $0.035^{*}$ & $9(13.0)$ & $0.038^{*}$ \\
\hline \multicolumn{10}{|l|}{$\begin{array}{l}\text { Contact with } \\
\text { other dogs }\end{array}$} \\
\hline No & 104 & $7(6.7)$ & & $8(7.7)$ & & $13(12.5)$ & & $15(14.4)$ & \\
\hline Yes & 96 & $5(5.2)$ & 0.877 & $7(7.3)$ & 1.000 & $23(24.0)$ & $0.054^{*}$ & $13(13.5)$ & 1.000 \\
\hline \multicolumn{10}{|l|}{$\begin{array}{l}\text { Contact with } \\
\text { cattle }\end{array}$} \\
\hline No & 199 & $12(6.0)$ & & $15(7.5)$ & & $35(17.6)$ & & $27(13.6)$ & \\
\hline Yes & 1 & $0(0.0)$ & 1.000 & $0(0.0)$ & 1.000 & $1(100.0)$ & $0.180^{*}$ & $1(100.0)$ & $0.140^{*}$ \\
\hline \multicolumn{10}{|l|}{$\begin{array}{l}\text { Contact with } \\
\text { horses }\end{array}$} \\
\hline No & 199 & $12(6.0)$ & & $15(7.5)$ & & 35 (17.6) & & $27(13.6)$ & \\
\hline Yes & 1 & $0(0.0)$ & 1.000 & $0(0.0)$ & 1.000 & $1(100.0)$ & $0.180^{*}$ & $1(100.0)$ & $\begin{array}{l}0.140^{*} \\
\text { continue }\end{array}$ \\
\hline
\end{tabular}


continuation

Contact with cats

No

Yes

Contact with goats/sheep

$$
\text { No }
$$

Yes

Contact with wild animals

No
Yes

Environment

$$
\begin{aligned}
& \text { Soil } \\
& \text { Cement }
\end{aligned}
$$

\section{Clean} environment

\begin{tabular}{|c|c|c|c|c|c|c|c|c|c|}
\hline No & 24 & $1(4.2)$ & & $2(8.3)$ & & $3(12.5)$ & & $3(12.5)$ & \\
\hline Yes & 176 & $11(6.2)$ & 1.000 & $13(7.4)$ & 0.979 & $33(18.7)$ & 0.580 & $25(14.2)$ & 1.000 \\
\hline \multicolumn{10}{|l|}{ Walk } \\
\hline No & 125 & $11(8.8)$ & & $12(9.6)$ & & $22(17.6)$ & & $12(9.6)$ & \\
\hline Yes & 75 & $1(1.3)$ & $0.033^{*}$ & $3(4.0)$ & 0.239 & $14(18.7)$ & 1.000 & $16(21.3)$ & $0.035^{*}$ \\
\hline \multicolumn{10}{|c|}{ Travel } \\
\hline No & 191 & $12(6.3)$ & & $15(7.9)$ & & $35(18.3)$ & & $25(13.1)$ & \\
\hline Yes & 9 & $0(0.0)$ & 1.000 & $0(0.0)$ & 1.000 & $1(11.1)$ & 1.000 & $3(33.3)$ & $0.116^{*}$ \\
\hline \multicolumn{10}{|c|}{ Presence of mice } \\
\hline No & 188 & $12(6.4)$ & & $15(8.0)$ & & 35 (18.6) & & $25(13.3)$ & \\
\hline Yes & 12 & $0(0.0)$ & 1.000 & $0(0.0)$ & 0.605 & $1(8.3)$ & 0.698 & $3(25.0)$ & 0.381 \\
\hline
\end{tabular}

No
Yes

Vaccination

* Selected variables for multiple logistic regression $(p \leq 0.2)$.

For the owners, the serological diagnosis of leishmaniasis was conducted using IFAT at a cutoff dilution of 1:40 (Leishmania IFA IgG, Vircell, Granada, Spain). To identify anti-CD antibodies, a chemiluminescent microparticles immunoassay (CMIA) (Architect Chagas, Abbott Laboratories, Abbott Park, IL, USA) and IFAT were carried out at a cutoff dilution of 1:40 (IFI Chagas, Wama Diagnóstica, São Carlos, São Paulo, Brazil). Leptospirosis was diagnosed by ELISA (SERION
ELISA Leptospira IgG, Institut Virion/Serion, Würzburg, Germany). Antibodies against $T$. gondii were detected through CMIA (Architect Toxo IgG, Abbott Laboratories). All tests were conducted in the same private laboratory.

The collection of data from epidemiological surveys was used to conduct a risk factor analysis in two stages: univariate and multivariate. In the univariate analysis, the animals were divided into two groups-seropositive and seronegative-to 
compare all variables analyzed. Those variables with a statistical significance of $p \leq 0.2$ using the Chisquare test or Fisher's exact test (ZAR, 1999) were selected for multivariate analysis using multiple logistic regression (HOSMER; LEMESHOW, 2000). For multiple analyses, a value of $p<0.05$ was considered statistically significant. All analyses were performed using SPSS 20.0 software.

\section{Results and Discussion}

Of the 200 animals studied, twelve $(6.0 \% ; 95 \%$ confidence interval $[\mathrm{CI}]=2.7-9.3 \%$ ) were identified as seropositive for CVL, fifteen $(7.5 \%$; $95 \% \mathrm{CI}=$ $3.8-11.2 \%)$ for $\mathrm{CD}$, thirty-six $(18.0 \%$; $95 \% \mathrm{CI}=$ $12.7-23.3 \%$ ) for toxoplasmosis and twenty-eight $(14.0 \% ; 95 \%=9.2-18.8 \%)$ for leptospirosis. Table 1 shows the results of the univariate analysis of the obtained data; Table 2 illustrates the risk factors identified by logistic regression.

Table 2. Risk factors associated with seropositivity for visceral leishmaniasis, Chagas disease, toxoplasmosis, and leptospirosis in 200 dogs from December 2014 to October 2015, in Sertão of Paraíba, Brazil.

\begin{tabular}{lcccccc}
\hline \multicolumn{1}{c}{ Risk factor } & $\begin{array}{c}\text { Regression } \\
\text { coefficient }\end{array}$ & $\begin{array}{c}\text { Standard } \\
\text { error }\end{array}$ & Wald & $\begin{array}{c}\text { Odds ratio } \\
\text { (OR) }\end{array}$ & $\begin{array}{c}\text { 95\% confidence } \\
\text { interval (CI) }\end{array}$ & $\boldsymbol{P}$ \\
\hline Leishmaniasis & & & & & & \\
Age > 72 months & 2.199 & 0.860 & 6.542 & 9.01 & $1.67-48.59$ & 0.011 \\
$\begin{array}{l}\text { Soil environment } \\
\text { Chagas disease }\end{array}$ & 1.509 & 0.662 & 5.197 & 4.52 & $1.23-16.54$ & 0.023 \\
$\begin{array}{l}\text { Free housing living } \\
\text { conditions }\end{array}$ & 0.895 & 0.798 & 7.843 & 13.77 & $2.19-86.38$ & 0.005 \\
$\begin{array}{l}\text { Toxoplasmosis } \\
\begin{array}{l}\text { Free housing living } \\
\text { conditions }\end{array}\end{array}$ & 1.127 & 0.413 & 7.456 & 3.09 & $1.37-6.93$ & 0.006 \\
$\begin{array}{l}\text { Contact with cats } \\
\text { Leptospirosis }\end{array}$ & 1.127 & 0.535 & 4.432 & 3.09 & $1.08-8.81$ & 0.035 \\
Commercial food & 1.531 & 0.657 & 5.428 & 4.62 & $1.27-16.75$ & 0.020 \\
\hline
\end{tabular}

Regarding the distribution of the antibody titrations for CVL, three dogs presented a titer of 40 , four of 80 , one of 160 , two of 320 , and two of 640 . Logistic regression analysis allowed us to identify variables including an age of over 72 months and local environmental conditions (soil) as risk factors for L. chagasi infection. Previous studies have demonstrated that the prevalence of this canine disease differs based on their age range. This implies that the occurrence of leishmaniasis would be higher in adult dogs, as the incubation period would occur over a longer period of time, increasing the exposure of the host to this vector (ALMEIDA et al., 2010). In addition, soil composition was previously identified as risk factor for dogs in Paraíba (FERNANDES et al., 2016). In the locations used for this study, sanitation protocols are difficult to implement, which favors the accumulation of biological waste material. Moreover, different factors also contribute to the presence of other animals such as rodents, thus creating a favorable habitat for the proliferation of the vector, which uses organic material to lay eggs.

For $\mathrm{CD}$, seven, one, and seven dogs presented a titer of 40, 320, and 640, respectively. The variable of free housing was considered a risk factor for $T$. cruzi infections, as this type of living condition 
reinforces the peri-domestic cycle of the disease (FERNANDES et al., 2016); after the eradication of disease transmission in Brazil through its main vector, Triatoma infestans, other species of triatomines were introduced in urban and domestic areas, thus rendering both dogs and humans equally exposed.

Of the thirty-six animals identified as seropositive for $T$. gondii, twenty presented a titer of 16, twelve of 64, three of 256, and one of 1,024 . According to Larsson (1989), when an animal presents a titer at dilutions between 1:16 and 1:256 in immunofluorescence reactions, it means that at some point in its life, the animal came into direct contact with Toxoplasma gondii; owing to its immunological response, it was able to overcome any major morbidity, leaving only a permanent immunological scar. Only one seropositive animal presented a high titration (1:1,024), suggesting a recent infection occurred, although there was no evidence of clinical symptoms. The variables of free housing and contact with cats have been pointed out as additional risk factors. The latter is consistent with the epidemiology of the disease, as feline species are presented as definitive hosts and dissemination agents of $T$. gondii in the environment. Free housing was also considered a risk factor in other studies, thus confirming the importance of contamination from external to domestic environments as a propitiator of higher rates of $T$. gondii infection (CAÑÓN-FRANCO et al., 2004).

For leptospirosis, the serovar $L$. icterohaemoragiae $(12 / 28)$ was the most common, followed by L. pomona (5/28), L. grippotyphosa (4/28), L. canicola (2/28), L. autumnalis (2/28), L. cynopteri (1/28), L. tarassovi (1/28), and L. wolfii $(1 / 28)$, which presented titers that varied from 100 to 800 . It is important to note that most animals were not immunized with polyvalent vaccines, suggesting that these titers probably corresponded to a natural infection. The serogroup L. icterohaemorrhagiae uses syntropic rodents as its main maintenance hosts. Of these animals, Rattus novergicus (brown rat) occupies a prominent position, although $R$. rattus (black rat) and Mus musculus (mouse) are also able to clear pathogenic Leptospira. These rodents are resistant to clinical signs of the disease and act as healthy hosts, harboring the agent inside their kidney tubules. The agent is secreted into the environment through urine, contaminating water and food offered to dogs, as well as through tools used when handling the animals, such as drinking fountains and feeders (PAES, 2016). A diet consisting of commercial food was identified as a risk factor, suggesting that the unsafe storage of food might favor the occurrence and maintenance of potential reservoirs of Leptospira, such as rodents (AGUIAR et al., 2007). Although it was not part of our epidemiological survey, during the interviews it was noted that food was stored in plastic bags and/ or kept in the feeder overnight.

Mixed reactivity was as follows: three animals were seropositive for $\mathrm{CVL}$ and $\mathrm{CD}$, three for CVL, CD, and toxoplasmosis, and two for CD and toxoplasmosis. Some studies suggest that the immunosuppression caused by Leishmania spp. could increase the susceptibility of dogs to secondary infection by agents such as $T$. gondii (GENNARI et al., 2006). It is noteworthy to emphasize the presence of endemic areas for CVL and CD in South America, where the possibility of mixed infections is high (LUCIANO et al., 2009; FERNANDES et al., 2016).

Of the human contactants, twenty-three dog owners from different homes agreed to participate in the study. Of these, eight were tested for leishmaniasis, three for $\mathrm{CD}$, nine for toxoplasmosis, and eleven for leptospirosis. Five individuals were tested for more than one disease. Of the individuals screened for toxoplasmosis, four were seropositive; this corresponded to a frequency of $44.4 \%$. All individuals were negative for the other diseases tested.

With the aim to evaluate the zoonotic potential of dogs, these animals were often used as sentinels 
to investigate the occurrence of and risk factors associated with the diseases studied here. Previous studies have shown that some dog habits, such as rolling in dirt and eating feline feces, increase the risk of contamination in domestic environments and expose owners to toxoplasmosis (LANGONI et al., 2006). However, there are few studies concomitantly investigating the incidence of toxoplasmosis in dogs and humans (SANTOS et al., 2009). In this work, we observed that toxoplasmosis presented the highest frequency among tested dogs. Although this positive result is still considered low, it was observed that all seropositive owners had seropositive dogs. Therefore, this information on the prevalence of toxoplasmosis infection in the canine population is an indicator of domestic environment contamination and potential risk for human beings. Indeed, both human and dog exposure occur through the same source of infection (LANGONI et al., 2006).

\section{Conclusion}

The results obtained allow us to conclude that four zoonoses were present in the municipality evaluated in this study; this should raise concerns regarding the possibility of infection in humans. Based on our risk factor analysis, we suggest that taking greater care of soil environments where dogs are raised, avoiding free housing, and improving the storage conditions of food offered to the animals are all factors that can reduce the risk of developing these diseases.

\section{Acknowledgments}

The authors would like to thank the pharmaceutical biochemist Huarandir Nunes dos Santos and the biomedical professional Marina Santiago da Costa for collecting human blood samples. We also would like to thank CAPES for the $\mathrm{PhD}$ scholarship to Annielle Regina da Fonseca Fernandes.

\section{References}

AGUIAR, D. M.; CAVALCANTE, G. T.; MARVULO, M. F. V.; SILVA, J. C. R.; PINTER, A.; VASCONCELLOS, S. A.; MORAIS, Z. M.; LABRUNA, M. B.; CAMARGO, L. M. A.; GENNARI, S. M. Fatores de risco associados à ocorrência de anticorpos anti-Leptospira spp. em cães do município de Monte Negro, Rondônia, Amazônia Ocidental Brasileira. Arquivo Brasileiro de Medicina Veterinária e Zootecnia, Belo Horizonte, v. 59, n. 1, p. 70-76, 2007.

ALMEIDA, A. B. P. F.; MENDONÇA, A. J.; SOUSA, V. R. F. Prevalência e epidemiologia da leishmaniose visceral em cães e humanos, na cidade de Cuiabá, Mato Grosso, Brasil. Ciência Rural, Santa Maria, v. 40, n. 7, p. 1610-1615, 2010.

ALVES, C. J.; VASCONCELLOS, S. A.; MORAIS, Z. M.; ANDRADE, J. S. L.; CLEMENTINO, I. J.; AZEVEDO, S. S.; SANTOS, F. A. Avaliação dos níveis de aglutininas antileptospiras em gatos no município de Patos, PB. Revista Clínica Veterinária, São Paulo, v. 5, n. 46, p. 48-54, 2003.

BATISTA, C. S. A.; AZEVEDO, S. S.; ALVES, C. J.; VASCONCELOS, S. A.; MORAIS, Z. M.; CLEMENTINO, I. J.; LIMA, F. S.; ARAUJO NETO, J. O. Soroprevalência de leptospirose em cães errantes da cidade de Patos, Estado da Paraíba, Brasil. Brazilian Journal of Veterinary Research and Animal Science, São Paulo, v. 41, n. 02, p. 131-136, 2004.

CAMARGO, M. E. Fluorescent antibody test for the sorodiagnosis of American trypanosomiasis: technical modification employing preserved culture forms of Trypanosome cruzi in a slide test. Revista do Instituto de Medicina Tropical de São Paulo, São Paulo, v. 8, n. 5, p. 227-235, 1966. Available at: <https://www.ncbi. nlm.nih. gov/pubmed/4967348>. Accessed at: 5 jan. 2016.

CAMARGO, M. E. Improved technique of indirect immunofluorescence for serological diagnosis of toxoplasmosis. Revista do Instituto de Medicina Tropical de São Paulo, São Paulo, v. 6, n. 1, p. 117118, 1964. Available at: <https://www.ncbi.nlm.nih.gov/ pubmed/14177810>. Accessed at: 20 aug. 2016.

CAMARGO, M. E.; REBONATO, C. Cross reactivity in fluorescence tests for Trypanosoma and Leishmania antibodies. A simple inhibition procedure to ensure specific results. The American Journal of Tropical Medicine and Hygiene, Cleveland, v. 18, n. 4, p. 500505, 1966.

CAÑÓN-FRANCO, W. A.; BERGAMASCHI, D. P.; LABRUNA, M. B.; CAMARGO, L. M.; SILVA, J. C.; PINTER, A.; GENNARI, S. M. Occurrence of anti- 
Toxoplasma gondii antibodies in dogs in the urban area of Monte Negro, Rondônia, Brazil. Veterinary Research Communications, Heidelberg, v. 28, n. 2, p. 113-118, 2004.

DE NARDO, P. Veterinary enviromental epidemiology the case of respiratory patology in the dog. Annali dell Istituto Superiore di Sanita, Rome, v. 33, n. 4, p. $587-$ 593, 1997.

DUBEY, J. P.; LAM, T. T. H.; SUNDAR, N.; SU, C. Genetic characterization of Toxoplasma gondii isolates in dogs from Vietnam suggests their South American origin. Veterinary Parasitology, Amsterdam, v. 146, n. 3-4, p. 347-351, 2007.

FERNANDES, A. R. F.; PIMENTA, C. L. R. M.; VIDAL, I. F.; OLIVEIRA, G. C.; SARTORI, R. S.; ARAÚJO, R. B.; MELO, M. A.; LANGONI, H.; AZEVEDO, S. S. Risk factors associated with seropositivity for Leishmania spp. and Trypanosoma cruzi in dogs in the state of Paraiba, Brazil. Revista Brasileira de Parasitologia Veterinária, Jaboticabal, v. 25, n. 1, p. 90-98, 2016.

GENNARI, S. M.; FRANCO, W. A. C.; FEITOSA, M. M.; IKEDA, F. A.; LIMA, V. M. F.; AMAKU, M. Presence of anti- Neospora caninum and Toxoplasma gondii antibodies in dogs with visceral leishmaniosis from the region of Araçatuba, São Paulo, Brazil. Brazilian Journal of Veterinary Research and Animal Science, São Paulo, v. 43, n. 5, p. 613-619, 2006.

HOSMER, D. W.; LEMESHOW, S. Applied logistic regression. New York: John Wiley \& Sons, 2000. 375 p.

INSTITUTO BRASILEIRO DE GEOGRAFIA E ESTATÍSTICA - IBGE. Cidades. Brasília: Instituto Brasileiro de Geografia e Estatística, 2017. Disponível em: <https://cidades.ibge.gov.br/brasil/pb/brejo-do-cruz/ panorama $>$. Acesso em: 30 set. 2017.

LANGONI, H.; MODOLO, J. R.; PEZERICO, S. B.; SIlVA, R. C.; CASTRO, A. P. B.; SIlVA, A. V.; PADOVANI, C. R. Serological profile of anti- Toxoplasma gondii in apparently healthy dogs of the city of Botucatu, São Paulo state, Brazil. Journal of Venomous Animals and Toxins including Tropical Diseases, Botucatu, v. 12, n. 1, p. 142-148, 2006.

LARSSON, C. D. Diagnóstico laboratorial da toxoplasmose - reações utilizadas e interpretação clínica. Revista Cães e Gatos, Sorocaba, ano 4, n. 24, p. 5-11, jan./fev. 1989.
LILENBAUM, W.; VARGES, R.; MORAES, I. A.; FERREIRA, A. M. R.; PISSINATTI, A. Leptospiral antibodies in captive lion tamarins (Leontopithecus sp) in Brazil. The Veterinary Journal, London, v. 169, n. 3, p. 462-464, 2005. Available at: <http:/www.sciencedirect. com/science/article/pii/S1090023304000760>. Accessed at: 12 sept. 2016.

LUCIANO, R. M.; LUCHEIS, S. B.; TRONCARELLI, M. Z.; LUCIANO, D. M.; LANGONI, H. Avaliação da reatividade cruzada entre antígenos de Leishmania spp e Trypanosoma cruzi na resposta sorológica de cães pela técnica de imunofluorescência indireta (RIFI). Brazilian Journal of Veterinary Research and Animal Science, São Paulo, v. 46, n. 3, p. 181-187, 2009.

PAES, A. C. Leptospirose canina. In: MEGID J., RIBEIRO, M. G.; PAES A. C. Doenças infecciosas em animais de produção e de companhia. São Paulo: Roca, 2016. p. 356-377.

SANTOS, T. R.; COSTA, A. J.; TONIOLlO, G.; LUVIZOTTO, M. C. R.; BENETTI, A. H.; SANTOS, R. S.; MATTA, D. H.; LOPES, W. D. Z.; OLIVEIRA, J. A.; OLIVEIRA, G. P. Prevalence of anti-Toxoplasma gondii antibodies in dairy cattle, dogs, and humans from the Jauru micro-region, Mato Grosso state, Brazil. Veterinary Parasitology, Amsterdam, v. 161, n. 3-4, p. 324-326, 2009.

ULLMANN, L. S.; GUIMARÃES, F. F.; FORNAZARI, F.; TOMÉ, R. O.; CAMOSSI, L. G.; GRECA, H.; SILVA, R. C.; MENOZZI, B. D.; LANGONI, H. Ações de vigilância continuada, papel do cão como animal sentinela para toxoplasmose. Revista Brasileira de Parasitologia Veterinária, Jaboticabal, v. 17, p. 345-347, 2008. Suplemento 1.

WORLD ORGANISATION FOR ANIMAL HEALTH - OIE. Reference Laboratory Reports Activities. Paris: OIE, 2014. Available at: <http://www.oie.int/fileadmin/ Home/fr/Our_scientific_expertise/ reflabreports/2014/ report_204_2014_Leptospirosis_UNITED_KINGDOM. pdf $>$. Accessed at: 1 aug. 2016.

ZAR, J. H. Biostatistical analysis. $4^{\text {th }}$ ed. Upper Saddle River: Prentice Hall, 1999. 663 p. 
